\title{
JENIS DAN KEPADATAN TUNGAU DEBU RUMAH PADA BEBERAPA HABITAT DI RUMAH PENDERITA PENYAKIT ALERGI
}

\author{
${ }^{1}$ Wiska F. Ponggalunggu \\ ${ }^{2}$ Victor D. Pijoh \\ ${ }^{2}$ Greta J. P. Wahongan
}

\author{
${ }^{1}$ Kandidat Skripsi Fakultas Kedokteran Universitas Sam Ratulangi Manado \\ ${ }^{2}$ Bagian Parasitologi Fakultas Kedokteran Universitas Sam Ratulangi Manado \\ Email: wiskafp@gmail.com
}

\begin{abstract}
House dust mites are the most found allergens in homes scattered throughout the world that associated with allergic manifestations in the respiratory tract and skin, such as bronchial asthma, allergic rhinitis and atopic dermatitis. The most common house dust mite is from the family Pyroglyphidae, four of which have a close relationship with the incidence of allergy: Dermatophagoides pteronyssinus, Dermatophagoides farinae, Dermatophagoides microceras, and Euroglyphus maynei. This study aims to determine the type and density of house dust mites in several habitats in the homes of people with allergic diseases. This study is a descriptive study using cross-sectional method. Samples were dust in allergic patient's home in Malalayang I, taken from three habitats, namely bed (mattress and bed linen), bedrooms floor and sofa, as many as 96 samples. Of the 96 samples, there are 60 samples positive of dust mites and 36 negative samples. This study found 157 mites (124 adults and 33 larvae mites). Of the 124 adult mites were identified, there are 122 from order Astigmata with the dominant species is Dermatophagoides pteronyssinus, and two others of the order Prostigmata. In each habitat that is in the bed (mattress and bed linen), bedrooms floor and sofa, Pyroglyphidae is the most prevalent.
\end{abstract}

Keywords: house dust mite, allergies

\begin{abstract}
Abstrak. Tungau debu rumah (TDR) adalah alergen dalam rumah terbanyak yang tersebar di seluruh dunia yang dikaitkan dengan manifestasi alergi pada saluran pernapasan dan kulit, seperti asma bronkial, rinitis alergi dan dermatitis atopik. TDR yang paling sering ditemukan adalah dari famili Pyroglyphidae, empat di antaranya memiliki hubungan yang erat dengan kejadian alergi: Dermatophagoides pteronyssinus, Dermatophagoides farinae, Dermatophagoides microceras, dan Euroglyphus maynei. Penelitian ini bertujuan untuk mengetahui jenis dan kepadatan tungau debu rumah pada beberapa habitat di rumah penderita penyakit alergi. Penelitian ini adalah penelitian deskriptif dengan menggunakan metode crosssectional. Sampel penelitian adalah debu di rumah penderita alergi di Kelurahan Malalayang I yang diambil dari 3 habitat, yaitu tempat tidur (kasur dan sprei), lantai kamar tidur, dan sofa sebanyak 96 sampel. Dari 96 sampel, 60 sampel positif tungau debu dan 36 sampel negatif. Pada penelitian ini ditemukan 157 tungau (124 tungau dewasa dan 33 larva). Dari 124 tungau dewasa yang terindentifikasi, dari ordo Astigmata sebanyak 122 dengan spesies yang dominan adalah Dermatophagoides pteronyssinus, dan dua lainnya dari ordo Prostigmata. Pada masingmasing habitat yaitu di tempat tidur (kasur dan sprei), lantai kamar tidur dan sofa, famili Pyroglyphidae paling banyak ditemukan.
\end{abstract}

Kata kunci: tungau debu rumah, alergi 
Alergi adalah potensi terjadinya reaksi imun yang tidak diinginkan terhadap bahan yang biasanya tidak berbahaya dan banyak ditemukan di lingkungan. Respon tersebut merupakan hipersensitivitas terhadap pajanan ulangan dengan alergen yang menimbulkan pelepasan mediator inflamasi dan kelainan fungsi organ. Beberapa contoh penyakit alergi adalah rinitis alergi, asma bronkial, dan dermatitis atopik. ${ }^{1}$

Prevalensi dan morbiditas penyakit alergi tidak sama di berbagai negara. Rinitis alergi ditemukan pada sekitar 20\% populasi. Prevalensi dermatitis atopik ditaksir antara 9-21\% pada anak, sedang pada dewasa sekitar 2-10\%. ${ }^{1}$ Menurut data World Health Organization (WHO), 235 juta orang di dunia menderita asma. ${ }^{2}$ Global Initiative for Asthma (GINA) memperkirakan penderita asma akan meningkat menjadi 400 juta orang pada tahun 2025. ${ }^{3}$ Menurut Data Riset Kesehatan Dasar (Riskesdas) 2013, prevalensi asma di Indonesia adalah 4,5\%, dan di Sulawesi Utara sekitar 4,7\%. ${ }^{4}$

Menurut rute masuknya alergen ke dalam tubuh, alergen dibagi atas inhalan, ingestan, parenteral, dan kontaktan. Alergen dalam udara (inhalan) dapat berasal dari dalam dan luar rumah. ${ }^{1}$ Tungau debu rumah adalah alergen dalam rumah terbanyak yang tersebar di seluruh dunia yang dikaitkan dengan manifestasi alergi pada saluran pernapasan dan kulit, seperti asma bronkial, rinitis alergi dan dermatitis atopik. $^{5-7}$ Menurut WHO, sekitar 50-80 \% asma dan rinitis di seluruh dunia disebabkan oleh tungau debu rumah khususnya $D$. pteronyssinus dan $D$. farinae. ${ }^{8}$

Ada sekitar 16 genus dan 46 spesies dari tungau debu. Yang paling sering sering ditemukan adalah dari famili Pyroglyphidae, empat di antaranya memiliki hubungan yang erat dengan kejadian alergi: $D$. pteronyssinus, $D$. farinae, D. microceras, dan E. maynei. Spesies lain yang sering disebut sebagai tungau gudang namun sering juga ditemukan dalam rumah adalah Blomia tropicalis dari famili Glycyphagidae. ${ }^{9,10}$
Tungau debu rumah ditemukan terutama di tempat tidur, karpet, lantai. Beberapa penelitian menyebutkan bahwa tungau debu rumah paling banyak ditemukan di ruang tidur. ${ }^{11-14}$ Penelitian di Taas, Kecamatan Tikala dan Titiwungen Selatan, Kecamatan Sario, Kota Manado, 2013, menemukan Acarus sp. sebagai jenis tungau yang paling sering ditemukan. Sedangkan di Perkamil, Kecamatan Paal 2, Kota Manado, 2013, menemukan Dermatophagoides sp. sebagai spesies dominan. ${ }^{14}$ Penelitian Walangare et $\mathrm{al}^{12}$ yang dilakukan di Kota Manado mendapatkan proporsi sampel debu yang positif terdapat tungau sekitar $90 \%(0,9)$.

Berdasarkan latar belakang di atas, maka peneliti ingin melakukan penelitian untuk mengetahui jenis dan kepadatan tungau debu rumah pada beberapa habitat di rumah penderita penyakit alergi.

\section{METODE PENELITIAN}

Penelitian ini adalah penelitian deskriptif dengan menggunakan metode cross-sectional. Penelitian dilaksanakan di rumah-rumah penderita alergi di Kelurahan Malalayang I, Kecamatan Malalayang, Kota Manado. Penelitian ini berlangsung dari Oktober 2014 - Januari 2015.

Sampel penelitian adalah debu di rumah penderita alergi di Malalayang I yang diambil dari 3 habitat, yaitu tempat tidur (kasur dan sprei), lantai kamar tidur, dan sofa. Sampel dikumpulkan dengan menggunakan metode quota sampling. Untuk menentukan jumlah sampel minimal yang diperlukan pada penelitian ini menggunakan rumus untuk penelitian deskriptif kategorik. ${ }^{15}$

$$
n=\frac{Z \alpha^{2} P Q}{d^{2}}
$$

$\mathrm{n}=$ jumlah sampel minimal

$\mathrm{Z}=$ tingkat kepercayaan (untuk $\mathrm{Z}=90 \%$, nilainya $Z \alpha=1,64)$

$\mathrm{P}=$ proporsi sampel debu yang positif terdapat tungau

$\mathrm{Q}=1-\mathrm{P}=0.1$ 
$\mathrm{D}=$ limit dari error atau presisi absolut

$$
n=\frac{(1.64)^{2} 0.9(0.1)}{(0.05)^{2}}=96
$$

Berdasarkan rumus di atas, maka besar sampel minimal untuk penelitian ini adalah 96 sampel.

Kriteria inklusi pada penelitian ini ialah rumah penderita alergi, asma, rinitis, dan dermatitis atopik. Kriteria eksklusi berupa rumah dihuni kurang dari 1 tahun dan pemakaian kasur dan sofa yang kurang dari 1 tahun.

Alat dan bahan yang digunakan dalam penelitian ini adalah penghisap debu, kain sifon, wadah plastik, kertas label, saringan, cawan petri, timbangan, larutan Hoyers, eosin, pipet tetes, object glass, deck glass, mikroskop cahaya dan mikroskop stereoskopik, kawat dan cat kuku. Sampel debu yang diperoleh dibawa ke laboratorium Parasitologi Fakultas Kedokteran Unsrat untuk diperiksa. Sampel debu ditimbang, kemudian diperiksa dibawah mikroskop stereoskopik untuk menemukan tungau yang ada. Tungau debu rumah yang ditemukan dibuat preparat kemudian dilihat dibawah mikroskop streoskopik untuk diidentifikasi berdasarkan kunci MJ Collof et al.

\section{HASIL DAN BAHASAN}

Sampel debu diperoleh dari 32 rumah penderita alergi di Kelurahan Malalayang I (Tabel 1).

Tabel 1. Distribusi rumah penderita alergi berdasarkan jenis alergi

\begin{tabular}{lcc}
\hline \multicolumn{1}{c}{ Jenis Alergi } & Jumlah & $\mathbf{\%}$ \\
\hline Asma & 7 & 21.9 \\
Rinitis & 11 & 34.4 \\
Dermatitis atopik & 12 & 37.5 \\
Konjungtivitis & 2 & 6.3 \\
\hline Total & $\mathbf{3 2}$ & $\mathbf{1 0 0}$ \\
\hline
\end{tabular}

Tungau debu rumah dapat hidup di berbagai habitat seperti tempat tidur (sprei, kasur, bantal), karpet, lantai dan juga dapat ditemukan di luar rumah, misalnya pada sarang burung dan kandang ayam. ${ }^{11}$ Pada penelitian ini, sampel dibatasi hanya pada 3 habitat yaitu tempat tidur (kasur dan sprei), lantai kamar tidur, dan sofa.

Walaupun tidak semua sampel positif tungau, namun pada semua rumah ditemukan tungau debu. Ada 36 sampel yang negatif (Tabel 2 dan 3).

Tabel 2. Jumlah sampel debu yang positif dan negatif tungau debu

\begin{tabular}{lcc}
\hline \multicolumn{1}{c}{ Hasil } & Jumlah & \% \\
\hline Tungau (-) & 36 & $37.5 \%$ \\
Tungau (+) & 60 & $62.5 \%$ \\
\hline Total Sampel & 96 & $100 \%$ \\
\hline
\end{tabular}

Pada penelitian ini, dari 32 rumah yang dilakukan pengambilan sampel debu, semua rumah setidaknya memiliki 1 tungau pada sampel debunya. Hal ini disebabkan lokasi pengambilan sampel, yakni Kelurahan Malalayang 1 adalah daerah yang dekat dengan laut. Suhu udara pada pada rumah penderita alergi yang digunakan sebagai lokasi pengambilan sampel penelitian berkisar antara $29^{\circ}$ $32.6^{\circ} \mathrm{C}$. Kelembaban udara relatif tinggi yaitu $85 \%$. Untuk dapat bertahan hidup, tungau debu membutuhkan temperatur yang cukup tinggi yakni $25^{\circ}-30^{\circ} \mathrm{C}$ dan kelembaban antara $70-80 \%{ }^{11}$ Dengan demikian, suhu dan kelembaban Kelurahan Malalayang I Kota Manado, berada dalam rentang yang memungkinkan tungau untuk dapat berkembang dengan optimal.

Tabel 3. Habitat yang positif tungau debu rumah

\begin{tabular}{lc}
\hline Habitat & Jumlah \\
\hline Tempat tidur (kasur dan sprei) & 21 \\
Lantai kamar tidur & 16 \\
Sofa & 23 \\
\hline Total sampel positif & $\mathbf{6 0}$ \\
\hline
\end{tabular}

Sampel yang negatif tidak berarti tidak 
ada tungau pada habitat tersebut. Hal ini bisa disebabkan karena saat pengambilan sampel, area tersebut mungkin baru saja dibersihkan.

Penelitian ini menemukan bahwa kepadatan tungau debu paling tinggi terdapat di sofa yakni 25,51 tungau/gram debu. Kepadatan debu di kamar tidur lebih rendah yakni 10,26 tungau/gram debu. (Tabel 4). Hasil ini berbeda dengan penelitian sebelumnya yang dilakukan di Taas, Kecamatan Tikala ${ }^{12}$, dan di Perkamil,
Kecamatan Paal $2^{14}$ yang menemukan bahwa kepadatan tungau debu paling tinggi di kamar karena banyaknya skuama yang terlepas di tempat tidur, terakumulasi di kasur dan bantal saat tidur, membuat kamar tidur menjadi tempat dengan kepadatan tungau paling tinggi. Hal ini mungkin disebabkan dari hasil wawancara dengan penghuni rumah dimana sampel debu diambil, didapatkan bahwa sebagian besar dari mereka mengganti sprei tiap 2 minggu sekali atau setidaknya sekali sebulan.

Tabel 4. Kepadatan tungau debu pada masing-masing habitat

\begin{tabular}{ccccc}
\hline & $\begin{array}{c}\text { Tempat tidur (kasur } \\
\text { dan sprei) }\end{array}$ & $\begin{array}{c}\text { Lantai kamar } \\
\text { tidur }\end{array}$ & Sofa & Total \\
\hline Jumlah tungau & 31 & 27 & 99 & 157 \\
Berat total debu (gram) & 3.02 & 3.94 & 3.88 & 10.84 \\
Kepadatan tungau & 10.26 & 6.85 & 25.51 & 14.48 \\
(tungau/gram debu) & & & \\
\hline
\end{tabular}

Tabel 5. Hasil identifikasi tungau

\begin{tabular}{lcc}
\hline \multicolumn{1}{c}{ Jenis Tungau } & Jumlah & $\mathbf{\%}$ \\
\hline Larva $\quad$ Larva tidak terindentifikasi & 6 & $3.8 \%$ \\
$\quad$ Larva Pyroglyphidae \\
$\quad$ Larva Dermatophagoides & 4 & $1.9 \%$ \\
Dewasa & 14 & $9.6 \%$ \\
ASTIGMATA & & \\
$\quad$ Pyroglyphidae yang tidak terkategorikan & & $10.8 \%$ \\
$\quad$ Dermatophagoides sp. yang tidak terkategorikan & 49 & $31.2 \%$ \\
$\quad$ D. pteronyssinus & 23 & $14.6 \%$ \\
$\quad$ D. farinae & 18 & $11.5 \%$ \\
Glycyphagidae yang tidak terkategorikan & 1 & $0.6 \%$ \\
$\quad$ Blomia tropicalis & 12 & $7.6 \%$ \\
$\quad$ Austroglycyphagus sp. & 1 & $0.6 \%$ \\
$\quad$ Acaridae & 1 & $0.6 \%$ \\
PROSTIGMATA & & \\
$\quad$ Cheyletidae & 1 & $0.6 \%$ \\
Tarsonomidae & 1 & $0.6 \%$ \\
Tungau yang tidak teridentifikasi & 6 & $3.8 \%$ \\
Serangga bukan tungau & 3 & $1.9 \%$ \\
\hline Total & 157 & $100 \%$ \\
\hline
\end{tabular}

Tabel 6. Jenis tungau pada masing-masing habitat 


\begin{tabular}{lccc}
\hline \multicolumn{1}{c}{ Jenis Tungau } & $\begin{array}{c}\text { Tempat Tidur } \\
\text { (Kasur dan } \\
\text { Sprei) }\end{array}$ & $\begin{array}{c}\text { Lantai kamar } \\
\text { tidur }\end{array}$ & Sofa \\
\hline Larva & 1 & 2 & 3 \\
Larva tidak terindentifikasi & - & 1 & 3 \\
Larva Pyroglyphidae & 4 & 2 & 8 \\
Larva Dermatophagoides & & & \\
Dewasa & - & - & 17 \\
ASTIGMATA & 16 & 6 & 27 \\
$\quad$ Pyroglyphidae YTT & 7 & 7 & 9 \\
$\quad 1 \quad$ Dermatophagoides sp. YTT $\quad-$ pteronyssinus & - & 1 & 1 \\
$\quad$ D. farinae & 1 & - & 6 \\
$\quad$ Glycyphagidae YTT & - & 5 & - \\
$\quad$ Blomia tropicalis & - & 1 & 1 \\
$\quad$ Austroglycyphagus sp. & - & - & - \\
PROridae & 1 & 1 & 6 \\
$\quad$ Cheyletidae & - & - & 2 \\
$\quad$ Tarsonomidae & - & - & 99 \\
Tungau yang tidak teridentifikasi & 31 & 1 & \\
Serangga bukan tungau & & &
\end{tabular}

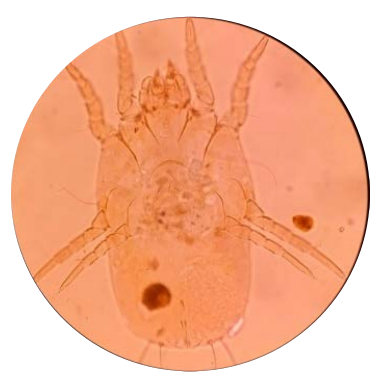

(a)

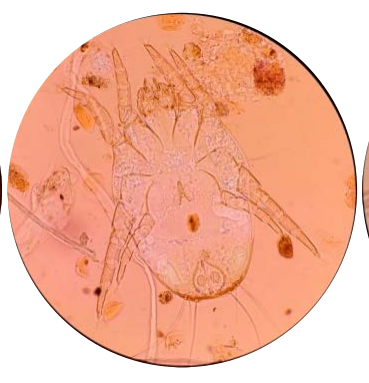

(b)

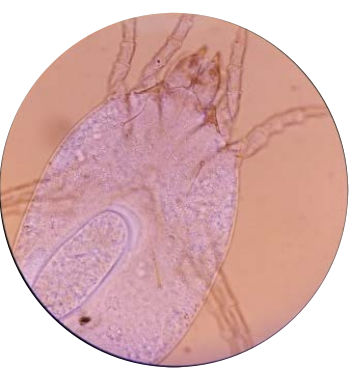

(c)

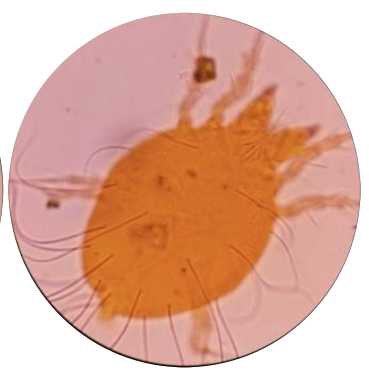

(d)

Gambar 1. Tiga spesies tungau yang ditemukan paling banyak dalam penelitian ini. (a) Dermatophagoides pteronyssinus betina (b) Dermatophagoides pteronyssinus jantan (c) Dermatophagoides farinae (d) Blomia tropicalis

Sofa yang ada sebagian besar sudah bertahun-tahun dan jarang dibersihkan. Hal ini disebabkan karena tidak tersedianya alat pembersih seperti vacuum cleaner, dan kesulitan untuk menjemur sofa karena terlalu berat. Ada juga sofa yang beralih fungsi sebagai sebagai tempat tidur sehingga lebih sering digunakan jika dibandingkan dengan kamar tidur.

Tungau dewasa maupun larva yang berhasil diidentifikasi didominasi oleh tungau dari ordo Astigmata. Famili Pyroglyphidae paling banyak ditemukan dengan spesies paling dominan adalah $D$. pteronyssinus, kemudian famili Glycyphagidae dengan spesies yang paling dominan adalah Blomia tropicalis (Tabel 5 dan 6).

Berbagai penelitian di negara-negara tropis lainnya menyatakan hal yang sama bahwa pada sampel debu rumah yang diamati, didominasi oleh Astigmata. 
Penelitian di Singapura menemukan $D$. pteronyssinus dari famili Pyroglyphidae sebagai tungau paling dominan kemudian Blomia tropicalis dari famili Glycyphagidae. $^{16}$ Blomia tropicalis dilaporkan biasanya ditemukan bersamasama dengan tungau dari famili Pyroglyphidae dan Acaridae. ${ }^{17}$ Arlian et al menemukan bahwa jumlah Blomia tropicalis cukup besar ditemukan pada rumah-rumah di daerah tropis dan subtropis bersama dengan tungau dari famili Pyroglyphidae. $^{18}$

Hasil penelitian ini sama dengan penelitian yang dilakukan di Galicia, Spanyol (2006), yang meneliti sampel debu yang diambil dari kasur yang dipakai oleh pasien alergi. Pada penelitian ini, dari 112 sampel debu, spesies yang dominan adalah D. pteronyssinus. ${ }^{19}$ Tungau debu rumah jenis $D$. pteronyssinus diketahui sebagai sumber utama penyebab alergi pada sistem respirasi. ${ }^{20}$ Zock et al, melakukan penelitian terhadap 228 siswa yang dilaporkan mengalami sesak napas disertai mengi dan/atau didiagnosa asma. Sampel debu diambil dari lantai kamar tidur penderita. Penelitian ini menemukan sejumlah $D$. pteronyssinus yang cukup banyak pada lantai berkarpet. ${ }^{21}$

Pagan et al melakukan penelitian terhadap 132 sampel debu rumah dan menemukan bahwa spesies yang paling sering ditemukan adalah $D$. farinae (36\%), D. pteronyssinus (32\%), dan Typhagus putrescentiae (5,3\%). Namun terdapat perbedaan signifikan pada daerah dengan keadaan iklim yang berbeda. Daerah yang dekat dengan laut mempunyai jumlah tungau yang lebih banyak jika dibandingkan dengan daerah yang jauh dari laut. Di daerah yang dekat dengan laut, $D$. pteronyssinus lebih banyak ditemukan, berbeda dengan daerah yang jauh dari laut, dimana $D$. farinae adalah spesies dominan. $^{22}$ Penelitian ini mendukung pendapat yang mengatakan bahwa $D$. pteronyssinus lebih menyukai daerah dekat dengan laut jika dibandingkan dengan daerah yang jauh dari laut. ${ }^{23}$ Hal ini sesuai dengan keadaan Kelurahan Malalayang I yang berada di dekat laut.

\section{SIMPULAN}

Kesimpulan yang diperoleh dari penelitian ini adalah tungau yang paling banyak ditemukan di Kelurahan Malalayang I adalah tungau dari famili Pyroglyphidae, dengan spesies yang dominan adalah Dermatophagoides pteronyssinus dengan kepadatan tungau yang paling tinggi terdapat di sofa.

\section{DAFTAR PUSTAKA}

1. Baratawidjaja KG, Regganis I. Alergi Dasar. Edisi 1. Jakarta : Interna Publishing. 2009:7-9,128,15961,268

2. World Health Organization. Asthma. 2013 Nov [cited 2015 Jan 22] Avaiable from: http://www.who.int/mediacentre/factsh eets/fs307/en/\#

3. Global Initiative for Asthma (GINA). Global strategy for ashtma management and prevention. Updated 2011. Cape Town: University of Cape Town Lung Institute; 2011.

4. Data Riskesdas 2013. 2013 Dec 1 [cited 2014 Sep 11] Available from: http://www.litbang.depkes.go.id/sites/d ownload/rkd2013/Laporan_Riskesdas2 013.PDF

5. Baerjee S, Resch Y, Chen K, Swoboda I, Focke-Tejki M, Blatt K et al. Der p 11 is a major allergen for house dust mite allergic patients suffering from atopic dermatitis. Journal of Investigative Dermatology. 2014;271:1-2

6. Xiang L, Fu Y, Wang J, Wang Q. The correlation between seasonal variation of house dust mite allergens exposure level in household and the level of asthma control in asthmatic children. Zhonghua Er Ke Za Zhi. 2014; 52(3):177-83.

7. Ramírez-Heredia J, Oífarrill-Romanillos PM, Guidos-Fogelbach G, MiyaguiNakamura RK, Segura-Méndez NH. Sensitization to house dust and storage mites in allergic adults from the South of Mexico City. Rev Alerg Mex. 2013 Jan-Mar

8. World Health Organization. The vectorborne human infections of Europe. WHO Regional Office for Europe. 
2004; 13:92

9. El-Dib N. House dust mites - what a might a mite do? Medical Sciences 11.

10. Collof MJ et al. Taxonomy and identification of dust mites. Allergy 1998; 53 (Suppl48): 7-12

11. Sutanto I, Ismid I, Sjarifuddin PK, Sungkar S. Parasitologi Kedokteran. Edisi 4. Jakarta: FKUI.2011:288

12. Walangare KR, Tuda JSB, Runtuwene J. Tungau debu rumah di Kelurahan Taas Kecamatan Tikala Kota Manado. Jurnal e-Biomedik. 2013; 1(1)439.

13. Worang I, Sorisi A, Pijoh VD. Tungau debu rumah yang ditemukan di Kelurahan Titiwungen Selatan Kecamatan Sario Kota Manado. 2013;1(1)319.

14. Breving RFR, Tuda JSB, Wahongan GJP. Tungau debu rumah yang ditemukan di Kelurahan Perkamil Kecamatan Paal 2 Kota Manado. 2013;1(2)859.

15. Dahlan MS. Langkah-langkah membuat proposal penelitian bidang kedokteran dan kesehatan - seri evidence based medicine (seri 3 edisi 2). Jakarta:Sagung Seto. 2012.

16. Kuo Ic, Yi FC, Cheong N, Shek LPC, Chew FT, Lee BW, et al. Sensitization to Blomia tropicalis and Dermatophagoides pteronyssinus-a comparative study between Singapore and Taiwan. Asian Pacific Journal of Allergy And Immunology. 1999;17:179-88

17. Mariana A, Ho TM, Sofian-Azirun M,
Wong AL. House dust mite fauna in the Klang Valley, Malaysia. 2000;31(4):712-21

18. Arlian LG, Vyszenski-Mother DL, Fernandez-Caldas E. Allerginicity of the mite, Blomia tropicalis. J Allergy Clin Immunol. 1993;91(5):1042-50

19. Boquete M, Iraola V, Fernández-Caldas E, Arenas Villaroel L, Carballada FJ, González de la Cuesta C, et al. House dust mite species and allergen levels in Galicia, Spain: a cross-sectional, multicenter, comparative study. J Investig Allergol Clin Immunol. 2006; 16(3): 169-76

20. Miranda O, Silva D, Fernandes J, Queiros M, Chiba H, Ynoue L, et al. Serum and salivary IgE, IgA, and IgG4 antibodies to Dermatophagoides pteronyssinus and its major allergens, Der p I and Der p 2, in allergic and non allergic children. Clinical and Developmental Immunology 2011;1-11

21. Zock JP, Brunekreef B, HazebroekKampschreur AAJM, Roosjen CW. House dust mite allergen in bedroom floor dust and respiratory health of children with asthmatic symptoms. Eur Respir J, 1994;7:1254-9

22. Pagán JA, Huertas AJ, Iraola V, Pinto H, Martínez R, Ramírez M et al. Mite exposure in a Spanish Mediterranean region. Allergologia et Immunopathologia, 2011; 40(2):929.

23. House dust mite. 2014 [cited 2015 Jan 15]. Avaiable from: www.betterhealth.vic.au 